\title{
An Unusual Cause of Rectal Pressure and Difficult Defecation: Giant Pelvic Myelolipoma
}

\section{Rektum Basısı ve Defekasyon Zorluğunun Alışılmadık Nedeni: Dev Pelvik Miyelolipom}

\author{
(1) Burak Sarılar, (1) Hüseyin Gökhan Yavaş, (1) Furkan Ufuk \\ Pamukkale University Faculty of Medicine, Department of Radiology, Denizli, Turkey
}

\section{HIIIIII| ABSTRACT}

Myelolipoma is a rare benign neoplasm consisting of mature adipose and haematopoietic tissues and usually found in the adrenal gland. However, myelolipoma can be rarely detected in extra-adrenal regions but often detected incidentally in imaging studies performed for other reasons or at autopsy. While adrenal myelolipomas are easily recognised given its typical imaging features, the diagnosis of extra-adrenal myelolipomas may be challenging. Herein, we aimed to present computed tomography and magnetic resonance imaging findings of pelvic extra-adrenal myelolipoma in a 77-year-old woman with hepatocellular carcinoma and to describe the differential diagnoses.

Keywords: Magnetic resonance imaging, computed tomography, pelvis, myelolipoma, lipomatous tumour

\section{|||||||||| ÖZ}

Miyelolipom, olgun adipöz ve hematopoietik dokudan oluşan ve genellikle adrenal bezde bulunan nadir benign bir neoplazmdır. Bununla birlikte, miyelolipom adrenal dışı bölgelerde nadiren tespit edilebilir ve sıklıkla başka nedenlerle yapılan görüntülemelerde veya otopside tesadüfen tespit edilir. Adrenal miyelolipomlar, tipik görüntüleme özellikleri nedeniyle kolayca tanınırken, adrenal dışı miyelolipomların teşhisi zor olabilir. Burada hepatoselüler karsinom tanılı 77 yaşındaki bir kadında pelvik ekstra-adrenal miyelolipomun bilgisayarlı tomografi ve manyetik rezonans görüntüleme bulgularını göstermeyi ve ayırıcı tanıları tanımlamayı amaçladık.

Anahtar Kelimeler: Manyetik rezonans görüntüleme, bilgisayarlı tomografi, pelvis, miyelolipom, lipomatöz tümör

\section{Introduction}

Myelolipomas are rare and benign tumours composed of variable amounts of haematopoietic elements and fatty tissue and usually located in the suprarenal glands. ${ }^{1}$ Moreover, cases have been reported in non-adrenal locations such as the presacral space, retroperitoneum, thoracic cavity, liver and stomach. 2,3,4,5 Myelolipomas are usually small, grow slowly and asymptomatic. Most of them are detected incidentally at autopsy or in imaging examinations performed for other reasons. While adrenal myelolipomas are easily recognised due to the typical imaging features, the diagnosis of extraadrenal myelolipomas (EAMs) may be challenging, and EAMs can be misdiagnosed as malignant tumours. ${ }^{1,2,3,4}$
Therefore, imaging features of EAMs should be well known to avoid aggressive surgical interventions.

\section{Case Report}

A 77-year-old woman, who was diagnosed with hepatitis B-related liver cirrhosis 6 years ago, presented with abdominal pain, but she was lost to follow-up for several years. She had a history of constipation and urinary incontinence for several years. Laboratory results revealed low haemoglobin level (12.8 g/dL; normal range, $14-16 \mathrm{~g} / \mathrm{dL})$ and platelet count (134,000; normal range: 150,000-400,000) and high alanine aminotransferase (65 IU/L; normal values, <41 IU/L) and alpha-fetoprotein level (344 ng/mL; normal values, $<5 \mathrm{ng}$ / 
$\mathrm{mL})$. Other laboratory test results were within normal limits. Abdominal ultrasonography (US) revealed heterogeneity and nodularity of the liver parenchyma, hypertrophy in the left lobe and atrophy in the right lobe, which were compatible with cirrhosis. Moreover, ascites and a heterogeneous, hypoechoic mass with a diameter of $4 \mathrm{~cm}$ at segment 5 of the liver were detected. Compared with abdominal US examination performed 3 years ago in an external centre, the lesion had newly appeared. Dynamic contrastenhanced computed tomography (CT) of the abdomen was performed, which revealed mild ascites and additional focus on segment 6 of the liver compatible with hepatocellular carcinoma (HCC). No metastasis was found on abdominal CT images, but a heterogeneous, well-defined fatty mass with solid components was detected in the presacral space (Figure 1). US-guided liver biopsy was performed with a preliminary diagnosis of HCC, and HCC was confirmed on histopathological examination. For further evaluation of the pelvic mass, magnetic resonance imaging (MRI) of the lower abdomen was performed, which showed a heterogeneous, well-defined, fatty mass with a pseudocapsule in the presacral space. The pelvic mass exhibited mild diffusion restriction with an apparent diffusion coefficient value of $0.92 \times 10-3 \mathrm{~mm}^{2} / \mathrm{s}$ and heterogeneous contrast enhancement (Figure 2). In the differential diagnosis of the lesion, EAM was primarily considered. A CT-guided tru-cut biopsy was performed considering the well-differentiated liposarcoma in the outer centre, and the pathological diagnosis was myelolipoma. Surgery was recommended, but the patient declined. Therefore, symptomatic treatment was started. In the control abdominal CT examination obtained 16 months later, the size and imaging features of the pelvic lesion were stable.

\section{Discussion}

Myelolipomas are benign and rare tumours composed of haematopoietic cells and adipocytes. ${ }^{1}$ The aetiology of myelolipomas is not well elucidated. Still, some theories suggest that myelolipomas result from a metaplastic

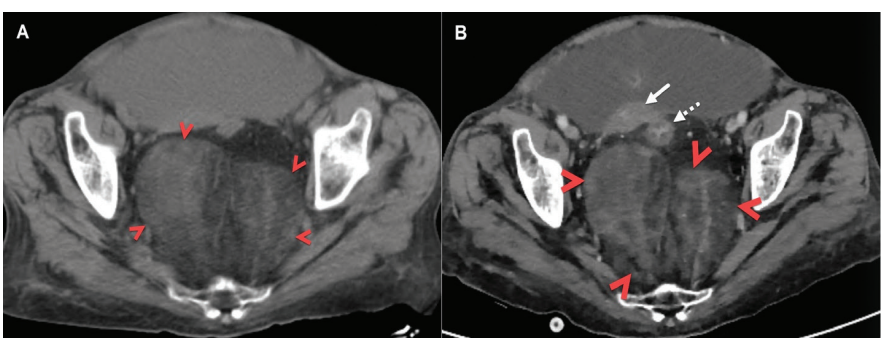

Figure 1. Axial unenhanced and (B) contrast-enhanced computed tomography image of the pelvis demonstrate a heterogeneous, welldefined and contrast-enhanced fatty mass with solid components in the presacral space change in response to infection, inflammation or stress. ${ }^{1,2,3}$ Although myelolipomas often present as an isolated adrenal myelolipoma, it could also appear in other locations such as the presacral space, retroperitoneum, thoracic cavity, liver and stomach. The presacral area is the most frequent location of extra-adrenal lesions. ${ }^{2,3,4,5}$ En bloc excision of the lesion with careful dissection is recommended in patients without symptoms. ${ }^{6,7}$ However, in the presented case, the patient refused surgery.

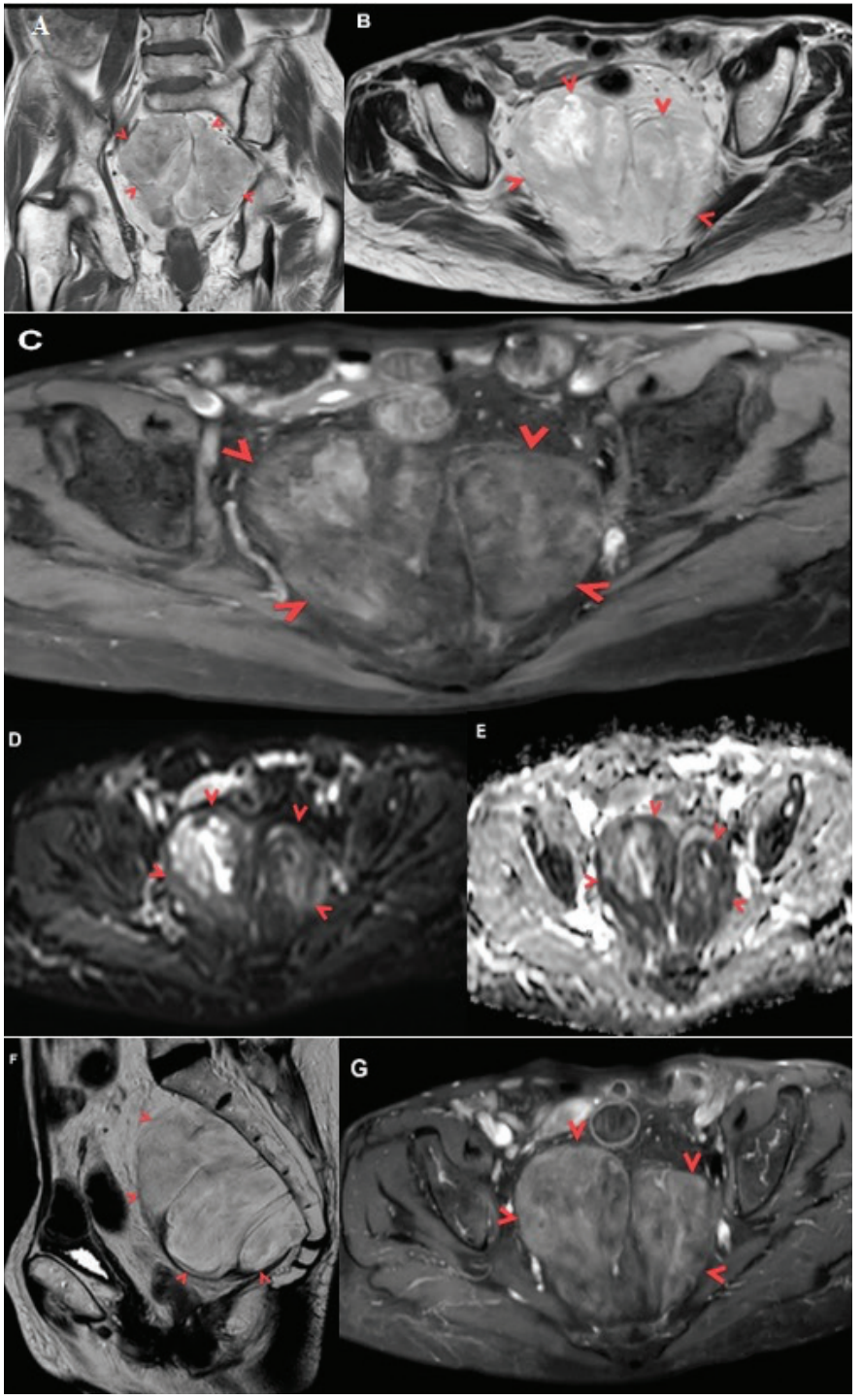

Figure 2. (A) Coronal T1-weighted and (B) Axial T2-weighted magnetic resonance (MR) images show well-defined, encapsulated and mildly hyperintense mass in the presacral space (arrowheads). Note the anteriorly displaced rectum (dashed arrow) and uterus (arrow). (C) Axial Tl-weighted fat-suppressed MR image shows signal dropout in the lesion due to the fat component (arrowheads). (D) Axial diffusion-weighted and (E) apparent diffusion coefficient (ADC) map image demonstrates mild diffusion restriction with an ADC value of $0.92 \times 10-3 \mathrm{~mm}^{2} / \mathrm{sec}$ (arrowheads). (F) Sagittal T2-weighted MR image shows a hypointense capsule of the presacral lesion (arrowheads). (G) Axial contrast-enhanced Tl-weighted fat-suppressed MR image shows heterogeneous contrast enhancement in the lesion (arrowheads) 
EAMs are almost always seen as a well-defined, round or oval fatty mass, as in the present case. EAMs are usually asymptomatic and detected incidentally. Rarely, EAMs may cause symptoms due to haemorrhage or mass effect when it reaches massive sizes. ${ }^{2,3}$ On abdominal CT, myelolipomas are usually seen as an encapsulated, welldefined, macroscopic fatty mass with regular septa or solid components. After intravenous administration of contrast medium, contrast enhancement is frequently seen in solid components of myelolipomas. On MRI, myelolipomas are detected as masses with mixed-signal intensities and partial hyperintense signal on $\mathrm{T} 2$-weighted (T2-W) and T1-W images due to the fat component of the masses, which show as signal dropout on fat-suppressed images, as in the present case. . $^{2,3,4}$

The differential diagnoses of fatty pelvic masses include liposarcoma, myelolipoma, pelvic lipomatosis and extramedullary haematopoiesis (EH) (Table 1) ${ }^{6,7}$

$\mathrm{EH}$ is a benign lesion of haematopoietic cells outside the medulla of the bone. While EH is usually found in the thoracic paravertebral space, presacral involvement is not unusual. $^{2}$ On CT, EH usually presents as a heterogeneous lesion close to the sacrum without bone erosion. On MRI, $\mathrm{EH}$ can be seen as a fatty mass with high-signal intensity on T1-W and T2-W images and as signal dropout on fatsuppressed images. Although the imaging features are generally similar to EAM, EH is often seen with multiple foci that usually hold the mediastinum and/or the paravertebral space. ${ }^{2,6,7}$

Liposarcomas are seen at any age and more often in male patients than in female patients. In liposarcomas, aggressiveness increases as fat content decreases. Unlike myelolipomas, the well-defined capsule in liposarcomas is not an expected imaging finding. Moreover, liposarcomas could show signs of invasion and may metastasise. ${ }^{3,4,6}$ When an ill-defined fatty mass without capsule (or pseudocapsule) and/or invasion features are seen on imaging, liposarcoma should be considered first in the differential diagnosis.

Pelvic lipomatosis is an uncommon entity characterised by excessive fat deposition in perirectal and perivesical spaces. Abdominal CT typically shows a non-encapsulated, symmetric and homogeneous excessive fatty tissue growth surrounding the pelvic organs. MRI shows similar features with CT. ${ }^{6,8}$ In myelolipoma, a solid component or septa is often seen, but not in pelvic lipomatosis.

In conclusion, EAM is a rare and benign entity that is generally found incidentally, as in the present case. It is essential to differentiate EAMs from aggressive tumours like liposarcomas. Differentiation of presacral myelolipoma from other presacral fatty masses could be challenging because imaging features may overlap. Well-defined, encapsulated and heterogeneous fatty presacral mass, without any haematologic disease, favours presacral myelolipoma than the others. Moreover, clinical, laboratory and descriptive

Table 1. Main differential diagnosis of presacral fatty masses and imaging features.

\begin{tabular}{|c|c|c|c|}
\hline Lesion & Imaging features & Clinical findings & $\begin{array}{l}\text { Contrast } \\
\text { enhancement }\end{array}$ \\
\hline Myelolipoma & $\begin{array}{l}\text { Encapsulated, well-defined mass with macroscopic } \\
\text { fatty tissue and solid areas; calcification may be } \\
\text { present. }\end{array}$ & $\begin{array}{l}\text { Usually asymptomatic and may cause } \\
\text { symptoms due to haemorrhage or mass } \\
\text { effect. }\end{array}$ & Yes* \\
\hline $\begin{array}{l}\text { Extramedullary } \\
\text { haematopoiesis }\end{array}$ & $\begin{array}{l}\text { Heterogeneous mass does not contain calcification, } \\
\text { usually seen in multiple foci that frequently hold the } \\
\text { mediastinum, and/or the paravertebral space. }\end{array}$ & $\begin{array}{l}\text { Chronic anaemia and haematological } \\
\text { disorders. }\end{array}$ & Yes* \\
\hline Liposarcoma & $\begin{array}{l}\text { Ill-defined fatty mass without capsule, invasion } \\
\text { features or metastasis. }\end{array}$ & $\begin{array}{l}\text { Usually asymptomatic at the early stage, } \\
\text { may be presented by mass effect or } \\
\text { metastasis. }\end{array}$ & Yes* \\
\hline Lipoma & $\begin{array}{l}\text { May contain a capsule; the mass effect is } \\
\text { asymmetrical. }\end{array}$ & Almost always asymptomatic. & No \\
\hline
\end{tabular}

*; in solid components 
features of patients such as age and medical history should also be taken into consideration.

Informed Consent: Obtained.

Peer-review: Externally and internally peer reviewed.

\section{Authorship Contributions}

Surgical and Medical Practices: B.S., H.G.Y., F.U., Concept: H.G.Y., Design: H.G.Y., Data Collection or Processing: B.S., H.G.Y., F.U., Analysis or Interpretation: H.G.Y., F.U., Literature Search: B.S., Writing: B.S., F.U.,

Conflict of Interest: No conflict of interest was declared by the authors.

Financial Disclosure: The authors declared that this study received no financial support.

\section{References}

1. Decmann Á, Perge P, Tóth M, Igaz P. Adrenal myelolipoma: a comprehensive review. Endocrine 2018;59:7-15.
2. Littrell LA, Carter JM, Broski SM, Wenger DE. Extra-adrenal myelolipoma and extramedullary hematopoiesis: Imaging features of two similar benign fat-containing presacral masses that may mimic liposarcoma. Eur J Radiol 2017:93:185-194.

3. Itani M, Wasnik AP, Platt JF. Radiologic-pathologic correlation in extraadrenal myelolipoma. Abdom Imaging 2014;39:394-397.

4. Butori N, Guy F, Collin F, Benet C, Causeret S, Isambert N. Retroperitoneal extra-adrenal myelolipoma: appearance in CT and MRI. Diagn Interv Imaging 2012;93:e204-e207.

5. Yildiz BD. Giant Extra-adrenal retroperitoneal myelolipoma with incidental gastric mesenchymal neoplasias. Int Surg 2015;100:1018-1020.

6. Hain KS, Pickhardt PJ, Lubner MG, Menias CO, Bhalla S. Presacral masses: multimodality imaging of a multidisciplinary space. Radiographics 2013;33:1145-1167.

7. Lee JJ, Dickson BC, Sreeharsha B, Gladdy RA, Thipphavong S. Presacral myelolipoma: diagnosis on imaging with pathologic and clinical correlation. AJR Am J Roentgenol 2016;207:470-481.

8. Zhang Y, Wu S, Xi Z, Wang X, Jiang X. Measuring diagnostic accuracy of imaging parameters in pelvic lipomatosis. Eur J Radiol 2012;81:31073114. 